\title{
SILENCING OF THE PATHOGENS - A REVOLUTIONARY PLANT MOLECULAR DEFENCE SYSTEM FOR PATHOGEN RESISTANCE
}

\author{
C.C. EADY ${ }^{1,2}$, H.J. RIDGWAY ${ }^{1}$, S.R. BULMAN ${ }^{1,2}$, A. STEWART ${ }^{1}$ \\ and A.J. CONNER ${ }^{1,2}$
}

\author{
${ }^{1}$ National Centre for Advanced Bio-Protection Technologies, PO Box 84, \\ Lincoln University \\ ${ }^{2}$ Crop \& Food Research, Private Bag 4704, Christchurch \\ Correspondingauthor: eadyc@crop.cri.nz.
}

\begin{abstract}
A recent advance in biotechnology has been the understanding of gene silencing. The process, elucidated in Caenorhabditis elegans and known as RNA interference (RNAi), is a vital defence mechanism in plants, fungi and arthropods. Key aspects of RNAi are specificity for precise silencing of RNA sequences; ability to transfer silencing from cell to cell and host to non-host; and potential to function in many organisms. This work investigates whether a plant-produced RNAi signal can induce specific gene silencing in non-viral pathogens that have intimate contact with host cytoplasm. By transforming a plant pest with the $g f p$ gene, and subsequently introducing RNAi constructs targeting the $g f p$ sequence, it should be possible to observe a $g f p$ silencing response. In concurrent experiments appropriate plant pathogens that have intimate connections with host cytoplasm, such as Sclerotinia sclerotiorum and Plasmodiophora brassicae, will be transformed with the $g f p$ gene and used to challenge the RNAi expressing host plant. If the system is functional, then the silencing of pathogen GFP expression should be observed upon infection of the RNAi expressing host plant. Future work will identify genes essential to pathogenicity of target pathogens and use these to design RNAi constructs for plant transformation.
\end{abstract}

\section{DEVELOPING ACTION THRESHOLDS FOR APHIDS TRANSMITTING BYDV IN AUTUMN SOWN WHEAT}

\author{
G.O. LANKIN ${ }^{1}$, D.A.J. TEULON ${ }^{2}$, S.P. WORNER ${ }^{1}$ \\ and M.A.W. STUFKENS ${ }^{2}$

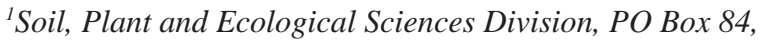 \\ Lincoln University, Canterbury \\ ${ }^{2}$ Crop \& Food Research, Private Bag 4704, Christchurch \\ Corresponding author: teulond@crop.cri.nz
}

Work to establish action thresholds, based on field sampling for aphids transmitting barley yellow dwarf virus (BYDV) in autumn sown wheat, was undertaken in the 2000-01 season. Field trials, each with three sowing dates (early April to late May 2000), were established at three sites in Canterbury. Paired half plots were (i) sprayed regularly with insecticides to minimise aphid infestation and virus infection, and (ii) left unsprayed during the period of greatest susceptibility to BYDV (emergence to early tillering). The development of action thresholds was precluded by low aphid numbers and virus incidence, and lack of differences in yield parameters between the two treatments at all sites and on all sowing dates. The difficulty of establishing aphid numbers at low infestation levels may preclude the use of aphid field samples for developing action thresholds for aphid control in autumn sown winter wheat. 